\title{
Central nervous system involvement in acute lymphoblastic leukemia: diagnosis by immunophenotyping
}

\section{Infiltração do sistema nervoso central na leucemia linfoide aguda: diagnóstico pela técnica de imunofenotipagem}

Camila Silva Peres Cancela ${ }^{1}$; Mitiko Murao²; Marcelo Eduardo de Lima Souza33; José Márcio Barcelos; Vírginia Miguel Furtado ${ }^{4}$; Maria Luiza Silva ${ }^{5}$; Marcos Borato Viana ${ }^{6}$; Benigna Maria de Oliveira ${ }^{7}$

\begin{abstract}
The central nervous system is the most commonly affected extramedullary site in acute lymphoblastic leukemia. Although morphologic evaluation of the cerebrospinal fluid has been traditionally used for diagnosing central nervous system involvement, it is a method of low sensitivity. The present study aimed at evaluating the use of immunophenotyping in the detection of blasts in the cerebrospinal fluid from children and adolescents with acute lymphoblastic leukemia.
\end{abstract}

Key words: acute lymphoblastic leukemia; central nervous system; cerebrospinal fluid; immunophenotyping.

\section{INTRODUCTION}

The central nervous system (CNS) is the most commonly affected extramedullary site in acute lymphoblastic leukemia (ALL). CNS involvement in ALL is classically defined by the presence of more than 5 leukocytes/ $\mu l$ and the presence of blasts on microscopic examination after centrifugation of the cerebrospinal fluid (CSF) sample. The involvement of cranial nerves is also part of the diagnostic criteria for CNS involvement ${ }^{(3)}$. However, regardless of the number of cells, the presence of blasts in CSF at diagnosis has been associated with a higher incidence of relapse in the $\mathrm{CNS}^{(4)}$.

The cytological examination of CSF through microscope, a traditional method for assessing CNS involvement in ALL, is regarded as less sensitive ${ }^{(2,5)}$. Due to the importance of the diagnosis of leukemic infiltration in the CNS and its implications for prognosis and treatment of ALL, other methods for detecting neoplastic cells in CSF have been investigated, namely immunophenotyping (IMF) by flow cytometry (FC) ${ }^{(2,3,5,5)}$.

In this study, preliminary results will be presented with the aim to assess IMF by FC as a complementary method for evaluating CSF from children and adolescents with ALL.

\section{RETROSPECTIVE STUDY}

The study population consisted of patients aged under 16 years, with an initial diagnosis or relapse of ALL, treated at Universidade Federal de Minas Gerais-Clinical Hospital (HC-UFMG) from 2008 to 2012. Patients underwent IMF of CSF during the implementation

First submission on $04 / 11 / 12$; last submission on 31/03/13; accepted for publication on $02 / 04 / 13$; published on 20/08/13

1. Master's in Pediatrics by Universidade Federal de Minas Gerais School of Medicine (UFMG); doctor at the Pediatric Hematology Department of UFMG Clinical Hospital (HC-UFMG).

2. Master's in Pediatrics by UFMG School of Medicine; doctor at the Pediatric Hematology Department of UFMG Clinical Hospital.

3. Medical Resident in Clinical Pathology at UFMG; doctor at the Clinical Pathology Department of HC-UFMG.

4. Graduate Medical student at UFMG.

5. Doctor in Health Sciences by Instituto René Rachou-Fundação Oswaldo Cruz (FIOCRUZ)-Belo Horizonte; biochemical pharmacist at the Laboratory Medicine Department of

HC-UFMG.

6. Doctor in Pediatrics and Pediatric Sciences by Universidade Federal de São Paulo (UNIFESP); emeritus professor at the Pediatrics Department of UFMG.

7. Doctor in Pediatrics by UFMG School of Medicine; associate professor at the Pediatrics Department of UFMG; chief of the Pediatrics Department of UFMG. 
phase of the technique at the university laboratory in accordance with the protocol of the Brazilian Cooperative Group for the Treatment of Childhood Leukemia (Grupo Cooperativo Brasileiro para Tratamento da Leucemia Infantil [GBTLI]) LLA999 ${ }^{(1)}$. The project was approved by the Ethics Committee of UFMG (CAAE 02840203000-11).

The collection of CSF for IMF was performed in the following situations: a) first lumbar puncture in newly diagnosed patients, with collection of CSF for neoplastic cell screening and intrathecal chemotherapy, as outlined in the GBTLI protocols; b) at the time of diagnosis of medullary and/or extramedullary relapse; c) in the presence of clinical diagnosis suggestive of leukemic infiltration in the CNS at any time during treatment.

We collected $4 \mathrm{ml}$ of CSF, $1 \mathrm{ml}$ intended for routine examination and the remainder to IMF. Samples with hematorrhachis from patients with blast cells in the peripheral blood were discarded owing to possible contamination by neoplastic cells.

As to $\mathrm{FC}$, the samples were processed and analyzed within 12 hours after collection. The samples were concentrated by centrifugation at $500 \mathrm{~g}$ for 5 minutes, hence reducing the initial volume of $4 \mathrm{ml}$ to a final volume of $0.5 \mathrm{ml}$, which was aliquoted into three tubes: tube one with $0.1 \mathrm{ml}$ (control); tube two with $0.2 \mathrm{ml}$ and antibodies for mature T lymphocyte analysis (CD3/ $\mathrm{CD} 8 / \mathrm{CD} 45 / \mathrm{CD} 4)$; tube three with $0.2 \mathrm{ml}$ and $\mathrm{CD1a}$ antibodies or $\mathrm{CR} \alpha \mathrm{b} / \mathrm{CD} 7 / \mathrm{CD} 45 / \mathrm{CD} 3$ in the case of T-lineage ALL or CD10/ $\mathrm{CD} 34 / \mathrm{CD} 45 / \mathrm{CD} 19$ in the case of B-lineage ALL, depending on the immunophenotype at diagnosis. The sample tubes and antibodies were incubated in the dark for 30 minutes at room temperature, followed by addition of $2 \mathrm{ml}$ of lysis solution, incubation for 10 minutes (dark, room temperature), centrifugation and washing with solvent filtrate (500 g, 5 minutes). Samples were acquired on FACScalibur ${ }^{\circledR}$ with dual lasers and four-color detection. Due to the low cellularity of the samples, all the cells from each tube were acquired. Data were interpreted with CellQuest program (Becton Dickinson). Multiparametric analyses were performed based on morphological properties (size versus internal granularity) and fluorescence intensity (Figure). The detection of any number of cells with the same immunophenotypic profile found at diagnosis or relapse was considered CNS infiltration by ALL.

We analyzed 23 samples of CSF from 20 patients (Table). Patients were aged from 7 months to 15.8 years (mean: 4.2 years) at diagnosis. Nineteen patients had B-ALL and only one presented T-ALL.

In ten patients, the tests were performed at diagnosis of ALL (eight cases - samples 1, 7-10 and 12-14) or when there was medullary relapse (two cases - samples 5 and 11) in the absence of symptoms suggestive of CNS infiltration. The data related to blast screening by traditional cytological exam and IMF are described in the Table. None of these ten patients had subsequent diagnosis of leukemic infiltration in the CNS.

In four patients (five samples: 2, 6, 15, 17, 18), the tests were performed at diagnosis of ALL relapse, in the presence of symptoms or cytological alterations in CSF suggestive of infiltration of the CNS. One sample (\#6) was negative by both methods and another (\#15) was positive by both methods. In this sample, the traditional cytometry showed the presence of 454 cells/ $/ \mu \mathrm{l}$, which were characterized as blasts. The third sample (\#2) was positive for the presence of blasts only by IMF. The traditional cytometry showed only one cell/ $\mu l$. This patient had been diagnosed with infiltration of the CNS due to the presence of pleocytosis with blasts (33 cells/ $\mu \mathrm{l}$ ) in CSF collected one week prior to sample collection for IMF. The reduction in cell number was due to intrathecal chemotherapy, which was not sufficient to eradicate neoplastic infiltration.

In six patients (samples 3, 4, 16, 19, 20, 21, 22 and 23), samples were obtained during treatment of ALL, in the presence of symptoms or CSF cytology suggestive of infiltration. In all cases, samples were negative for the presence of blast cells in the CSF by IMF, hence aiding in the differential diagnosis of infiltration of the CNS. In one case, with pleocytosis ( 646 cells/pl) and atypical lymphocytes detected by the traditional method (36\%), the IMF

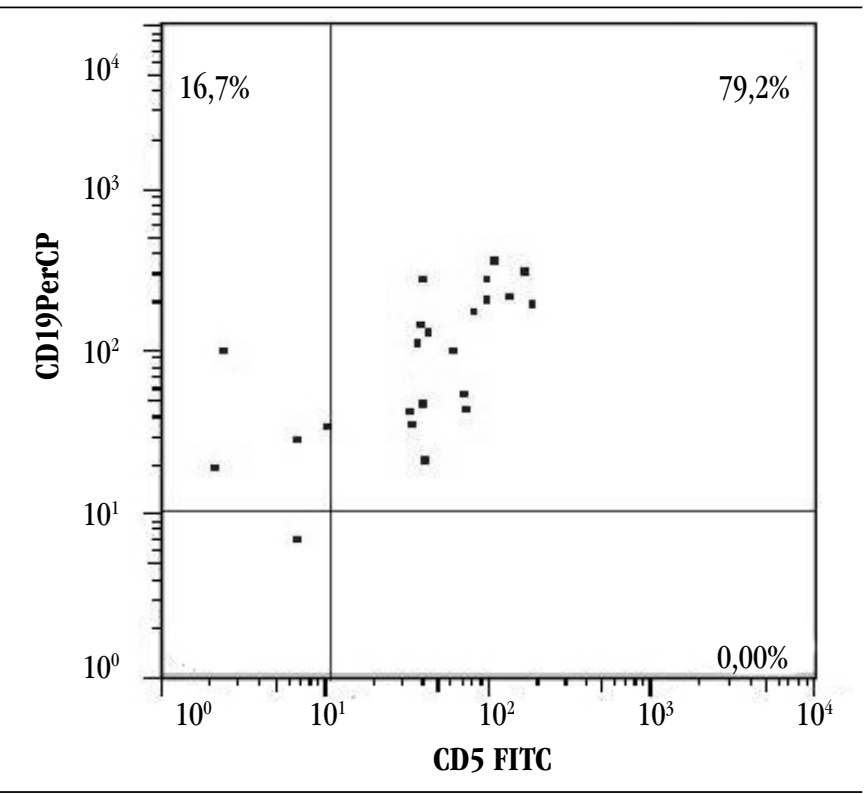

FIGURE - Dot-plot of the selected events according to FSC, SSC and CD 45 expression consistent with blast sites, with CD19 and CD5 (aberrant) immunostaining similar to diagnosis. CSF, sample 2, patient with B-ALL

FSC: forward scatter, SSC: side scatter; CSF: cerebrospinal fluid; ALL: acute lymphoblastic leukemia; FITC: fluorescein isothiocyanate; PerCP: peridinin chlorophyll-protein. 


\begin{tabular}{|c|c|c|c|c|}
\hline \multicolumn{5}{|c|}{ TABLE - Characteristics of 23 samples of CSF from children with acute lymphoblastic leukemia } \\
\hline Sample & Indication for the collection of CSF & $\begin{array}{c}\text { Cellularity of CSF } \\
\text { samples (nucleated cells/ } / \text { l) }\end{array}$ & $\begin{array}{l}\text { Blast screening by } \\
\text { traditional cytology }\end{array}$ & $\begin{array}{l}\text { IMF result: positive or negative } \\
\text { for the presence of blasts }\end{array}$ \\
\hline $1,8,9,13$ & Routine diagnosis & 0 & Negative & Negative \\
\hline 7 & Routine diagnosis & Data not found & Negative & Negative \\
\hline $10,12,14$ & Routine diagnosis & 0 & Negative & CNR \\
\hline 5 & Routine: medullary relapse & 0 & Negative & Inconclusive \\
\hline 11 & Routine: medullary relapse & 0 & Negative & CNR \\
\hline 2 & Medullary relapse and CNS: ACSF & 0 & Negative & Positive \\
\hline 6 & Ocular relapse & 0 & Negative & Negative \\
\hline 15 & $\begin{array}{l}\text { CNS relapse: signs of CNS infiltration } \\
\text { (visual deficit) }\end{array}$ & 454 & Positive (100\% blasts) & Positive \\
\hline 17 & $\begin{array}{l}\text { CNS relapse: involvement of cranial } \\
\text { nerves }\end{array}$ & 0 & Negative & Inconclusive \\
\hline 18 & $\begin{array}{c}\text { CNS relapse: involvement of cranial } \\
\text { nerves }\end{array}$ & 0 & Negative & CNR \\
\hline 3 & ACSF & 0 & $3 \%$ atypical lymphocytes & Negative \\
\hline 4 & ACSF & 0 & Negative & Negative \\
\hline 20 & ACSF & 3 & Negative & Negative \\
\hline 21 & ACSF & 0 & Negative & Negative \\
\hline 22,23 & ACSF & 1 & Negative & Negative \\
\hline 16 & Meningeal signs & 646 & $\begin{array}{l}36 \% \text { atypical } \\
\text { lymphocytes }\end{array}$ & Negative \\
\hline 19 & Suspected relapse: visual deficit & 2 & Negative & Negative \\
\hline
\end{tabular}

Patients with two collected samples: patient $A$ - samples 3 and $4 ; B-17$ and $18 ; C-21$ and 22.

CSF: cerebrospinal fluid; IMF: immunophenotyping, CNS: central nervous system; ACSF: altered CSF; CNR: cells not recovered.

proved to be useful in the differential diagnosis by demonstrating that they were reactive $\mathrm{T}$ lymphocytes. The etiologic diagnosis for this patient was viral meningitis.

Although the sample was relatively small and based on collected data and the literature, it was observed that IMF may assist in the evaluation of leukemic infiltration in the CNS and it is a relevant tool for the differential diagnosis in samples with pleocytosis and atypical lymphocytes or when the presence of blasts is suspected. Furthermore, it is helpful in situations with a small number of neoplastic cells in patients with mild infiltration, inasmuch as FC enables the detection of these cells in samples with low cellularity.

It is particularly worth mentioning that IMF does not preclude cytological analysis. Moreover, the impact of its incorporation in assessing prognosis of patients with ALL is still unclear. The authors are conducting a prospective study to evaluate the detection of leukemic cells in CSF by traditional cytological methods, IMF by $\mathrm{FC}$ and polymerase chain reaction.

\section{RESUMO}

O sistema nervoso central (SNC) é o sítio extramedular mais acometido na leucemia linfoide aguda. A avaliação morfológica do líquido cefalorraquidiano (LCR), apesar de ser o exame tradicional para o diagnóstico da infiltração leucêmica no SNC, é um método pouco sensivel. O presente estudo pretendeu avaliar a imunofenotipagem como método auxiliar na deteç̧ão de blastos no LCR em crianças e adolescentes com leucemia linfoide aguda.

Unitermos: leucemia linfoide aguda; sistema nervoso central; líquido cefalorraquidiano; imunofenotipagem. 


\section{REFERENCES}

1. BRANDALISE, S. R. et al. Benefits of the intermittent use of 6-mercaptopurine and methotrexate in maintenance treatment for lowrisk acute lymphoblastic leukemia in children: randomized trial from the Brazilian Childhood Cooperative Group-Protocol ALL-99. J Clin Oncol, v. 28, p. 1911-8, 2010.

2. BROMBERG, J. E. C. et al. CSF flow cytometry greatly improves diagnostic accuracy in CNS hematologic malignancies. Neurol, v. 68 , p. 1674-9, 2007.

3. NÜCKEL, H. et al. Detection of malignant haematopoietic cells in the cerebrospinal fluid by conventional cytology and flow cytometry. Clin Lab Haem, v. 28, p. 22-9, 2006.

4. PUI, C. H.; HOWARD, S. C. Current management and challenges of malignant disease in the CNS in paediatric leukaemia. Lancet Oncol, v. 9, p. 257-68, 2008.

5. SAYED, D. et al. Immunophenotyping and immunoglobulin heavy chain gene rearrangement analysis in cerebrospinal fluid of pediatric patients with acute lymphoblastic leukemia. Leuk Res, v. 33, p. 655-61, 2009.

6. SUBIRÁ, D. et al. Flow cytometry and the study of central nervous disease in patients with acute leukemia. Brit J Haemat, v. 112, p. 381-4, 2001.

\section{MAILING ADDRESS}

